IZA DP No. 6940

The Economics of Circular Migration

Amelie F. Constant

Olga Nottmeyer

Klaus F. Zimmermann

October 2012 


\title{
The Economics of Circular Migration
}

\author{
Amelie F. Constant \\ DIW DC, George Washington University and IZA
}

Olga Nottmeyer

$I Z A$

Klaus F. Zimmermann

IZA and Bonn University

\section{Discussion Paper No. 6940 \\ October 2012}

\author{
IZA \\ P.O. Box 7240 \\ 53072 Bonn \\ Germany \\ Phone: +49-228-3894-0 \\ Fax: +49-228-3894-180 \\ E-mail: iza@iza.org
}

\begin{abstract}
Any opinions expressed here are those of the author(s) and not those of IZA. Research published in this series may include views on policy, but the institute itself takes no institutional policy positions. The IZA research network is committed to the IZA Guiding Principles of Research Integrity.

The Institute for the Study of Labor (IZA) in Bonn is a local and virtual international research center and a place of communication between science, politics and business. IZA is an independent nonprofit organization supported by Deutsche Post Foundation. The center is associated with the University of Bonn and offers a stimulating research environment through its international network, workshops and conferences, data service, project support, research visits and doctoral program. IZA engages in (i) original and internationally competitive research in all fields of labor economics, (ii) development of policy concepts, and (iii) dissemination of research results and concepts to the interested public.
\end{abstract}

IZA Discussion Papers often represent preliminary work and are circulated to encourage discussion. Citation of such a paper should account for its provisional character. A revised version may be available directly from the author. 
IZA Discussion Paper No. 6940

October 2012

\section{ABSTRACT}

\section{The Economics of Circular Migration ${ }^{*}$}

Circular migration receives increasing attention due to its empirical relevance and as a policy concept to manage labor flows. This review discusses the advantages and disadvantages of circular movements for all parties. It studies the characteristics of circular movers worldwide and investigates the consequences of restrictive migration policies. Recent policy initiatives that aim to manage circular labor movement are also analyzed.

JEL Classification: J61, F22, F24

Keywords: geographic labor mobility, immigrant workers, international migration, remittances

Corresponding author:

Klaus F. Zimmermann

IZA

P.O. Box 7240

D-53072 Bonn

Germany

E-mail: zimmermann@iza.org

\footnotetext{
* We thank the anonymous referee for many helpful comments on earlier drafts. This paper will be published as a chapter in the forthcoming handbook of Constant and Zimmermann (2013).
} 


\section{Introduction}

The economics of migration literature saw an increasing interest in circular or repeat migration in the last two decades. At the same time, more and more programs concerning circular, revolving-door or "va-et-vient" migration started sprouting. By the year 2003 about 176 bilateral labor agreements have been signed among the Organization for Economic Cooperation and Development (OECD) countries alone (Newland et al., 2008). The importance of circular migration is underscored in the September 2005 communiqué on migration and development of the European Commission. The benefits of this labor movement "back and forth" between the home and host countries as well as labor movements involving third countries are listed in the Global Commission on International Migration (GCIM), the International Organization for Migration (IOM), the World Bank, the European Commission, and the House of Commons International Development Committee. The emerging importance of circular migration comes from its potential benefits to all countries involved in migration - be it the home or sending country, the host or receiving country or a third country, as well as to the migrants themselves.

Circular migration is not a new phenomenon or a new form of migration that suddenly appeared in the late 20th century. Looking back in time before even current national borders existed, many migration moves were de facto circular. Nomads, traders, and other seasonal laborers have been pursuing livelihood strategies by consciously taking advantage of opportunities in time and space in order to meet their needs under scarce resources. These needs include food security and access to institutions such as welfare, insurance, access to credit markets and risk diversification. In developing countries, circular migration has also been the road to eliminate poverty. 
In neoclassical economic theory ${ }^{1}$ in which rational labor migrants (the agents) have complete information, maximize utility under income constraints, make decisions at the margin, are optimizers, and pursue their own self-interest, it is natural that labor migrants move multiple times taking advantage of each situation in each country. Migrants optimize their income, savings, and investment strategies according to employment options and possibilities in both the home and host country and therefore improve their economic, social, and personal situation in every move and reach equilibrium (Constant and Zimmermann, 2011).

With technology allowing relative inexpensive travels and with communications allowing easier information access, the last couple of decades have witnessed circular migration in a larger scale. The creation of de facto migration markets ensures the efficient allocation of the scarce resource labor. In addition, circular migrants can be the buffer during periods of economic volatility and provide employers with a flexible labor force. Agreements about free labor mobility among countries can also foster circular migration. Such examples we find in the European Union of 27 and between Australia and New Zealand. ${ }^{2}$ Besides the receiving and sending countries, the migrants themselves can profit from repeated or circular moves.

As there are benefits there are also disadvantages and costs associated with circular migration that we will cite and discuss in a later section. In addition to theoretical arguments empirical studies can enlighten our understanding of circular migration and produce sound evidenced-based policy recommendations. Unfortunately, empirical evidence about circular migration is scarce and empirical analyses are limited due to missing or problematic data. A thorny issue in the data collection is whether a free democratic country should prohibit its residents from going abroad and/or gather 
information about their exit and re-entry. ${ }^{3}$ Even if this information could be obtainable, often reliable data do not exist because there is no matching information in home and source countries. A notable exception is the Mexican Migration Project (MMP), a binational study that surveys Mexicans on both sides of the U.S.-Mexican border since 1983. MMP allows for unique insights into the characteristics and determinants of circular migration. For example, these data show that Mexicans are indeed practicing circular migration; they are going to the US to work for a couple of months, and return to Mexico to live.

Other limitations arise because surveys may follow migrants only for a limited period of time and report observations of only parts of migrants' lives, or they even do not ask about migration history at all. Availability of better datasets such as the German Socio Economic Panel (GSOEP) that is done since 1984 and has rich information on before and after migration experiences make empirical studies on circular migration possible. According to the analysis of Constant and Zimmermann (2011), male and single migrants and those who have lower levels of education and are closer attached to the labor market are more likely circular migrants in their GSOEP sample. The New Immigrant Survey (NIS) is another exceptional migration dataset combining information from US administrative data as well as survey data. NIS contributes to our knowledge about circular migration by containing information about previous migration trips, their frequency and duration; it goes a step further to provide a glimpse into the behavior of migrants by offering information about possible previous repeated "illegal" trips to the US (Jasso et al., 2008).

One stunning finding about unintended consequences in policymaking became apparent from research on circular migration. Namely, restricting free circular mobility 
between home and host countries such as by introducing immigration quotas, increasing border protection, or enforcing return migration has often backfired. Flagrant examples are the increasing number of undocumented migrants living in the US and the permanence of the Turkish population in Germany. Instead of reducing labor migration, restrictions simply shift migration routes, change the type of migrants entering the country, and render sojourner migrants permanent. Entry without inspection and overstaying of legal entry visas increase making the number of migrants staying in the host country bigger. Lost options for legal re-entry makes families to unify and procreate in the host country.

The organization of this chapter is as follows: the next Section sets the stage for the economics of circular migration starting with a short presentation of definitions (2.1), and continuing with a detailed analysis of the benefits and costs of circular migration (2.2). Section 3.1 presents examples or case studies of the - often negative and counterproductive - consequences of restrictive migration policies; it also reviews empirical studies that analyze the characteristics of circular movers worldwide (3.2). The final Section concludes and offers policy recommendations as it also lists remaining gaps in the literature of circular migration.

\section{The Economics of Circular Migration}

\subsection{The Circular Migration Nomenclature}

Following Constant and Zimmermann (2011), we define circular migration as the systematic and regular movement of migrants between their homelands and foreign countries typically seeking work. ${ }^{4}$ Both skilled and unskilled workers practice circular migration. In the literature we find the following synonyms of circular migration: 
repeat, shuttling, rotating, multiple, cyclical, or circuit migration. For migration between the US and Puerto Rico, where there is free border mobility, the terms commuter or revolving-door migration have been used. Circular migration should be differentiated from the one-time emigration or out-migration and the eventual permanent return migration. Out-migration denotes a single move out of the home country and into the host country with no prospects of return - as was, for instance, the case for many Europeans immigrating to the U.S. between the $15^{\text {th }}$ and $17^{\text {th }}$ century. Similarly, return migration describes the only and final move back to the home country after a single migration trip.

Within the umbrella of circular migration there is seasonal and non-seasonal migration, mobility of professionals or brain circulation, and transnational entrepreneurs to name a few. The seasonal type of migration is the most popular and the probably most often occurring form of circular migration; it is taking place between high-income and low-income countries or regions during certain seasons such as during the summer to harvest of tomatoes. Unregulated systems and spontaneous circulation should also be differentiated from regulated systems and managed circulation (Newland et al., 2008). Unregulated systems are established by the migrants themselves. Examples of this type are the nomads and traders. Regulated systems on the other hand are based on collaborations and diplomatic agreements between states and/or employers. Examples of this type are the "bracero" program in the US in the 1940s, 1950s and early 1960s and the "guestworker" recruitment in many European countries in the 1950s, 1960s and 1970s. ${ }^{5}$ The type of circulating migration one observes among the EU member states and also among the former Soviet Union countries can be labeled transnational or commuter migrants. Zapata-Barrero et al. (2012) use the term “circular temporary labor 
migration” to focus on temporary workers who travel back and forth between countries over years for a substantial period of time of the year with no permanent nature. They discuss the Unió de Pagesos Programe of the largest agricultural business association in Catalonia/Spain with in particular Colombia as a role model for deregulated liberalization of mobility. It is seen as an innovative way to prevent illegal migration of low-skilled workers by regulating the flow.

However, the most important restricted circular migration in the world are the understudied and not yet well understood Chinese internal "floating populations" regulated by the Hukou system (Chan and Zhang, 1999, and Wang, 2004). An example for free circular migration is probably the new East European labor mobility generated by EU enlargement (Zaiceva and Zimmermann, 2008, Kahanec and Zimmermann, 2009). Circular migration has also been found in the South and East of the Mediterranean (Fargues, 2008).

A specific and distinct feature of circular migration, especially in its unregulated form, is its self-perpetuating nature (Massey and Espinosa, 1997; Constant and Zimmermann, 2011). Circular or repeat migration spawns migration-specific capital that causes and encourages the continuity of future migration. Like human capital and social capital, it is this migration-specific capital that ensures the exchange of information about the labor markets in the destination and the source country. More than that, migrant networks grease the wheels so migrants have current information about where to go, how to find jobs, what the market wage is, how to maneuver in the system, how to find places to live and do groceries, where to send their children to school, etc. These migrant networks are genuine sources of reliable information at any time in either 
country. In the neoclassical microeconomic setting this can be viewed as the "migration market" that reaches equilibrium wages and employment.

\subsection{Costs and Benefits of Circular Migration}

\section{2.a. Triple Win Scenario}

During the last decade, circular migration became very popular not as a description of reality but as a policy concept, particularly among government institutions. Besides the associated benefits for both sending and receiving countries, regulated circular migration programs offer the only legal loophole to labor migration. In the US, labor migration is only a small fraction of immigrants to the US, who are mostly tied to families and kin. Likewise, in Europe, labor migration to the EU from outside the EU countries is only possible under certain exceptions. Circular migration offers a way out of the stringent regulations, pacifies anti-migrant public opinion, and satisfies shortterm excess labor demand. With regard to the receiving countries circular migration enables filling labor market mismatches and gaps in a highly flexible way, provided that the right to enter and the requirement to leave were linked to the availability of work and the filter for migration is the labor market (Zimmermann, 2009).

A historic example of regulated circular migration is the bracero program in the US that started in the 1940s and continued until the 1960s to ease the labor shortages of the Second World War (Massey, 2011). According to the agreements between the US and Mexico, a Mexican laborer was allowed to come and work in the US for a limited period of time, especially in agriculture and railroads. In principle, temporary and shortterm agreements like this, aim at decompressing the labor markets and even increase competitiveness. Another famous example of controlled circular migration is the 
guestworker scheme that took place in Europe after the Second World War ${ }^{6}$. Several European countries such as France, the Netherlands, Denmark, Germany, and Switzerland delved into migrant recruitment of mostly low skilled laborers. Agreements with Southern European countries like Spain, Portugal, Greece, Italy, the former Yugoslavia, and Turkey as well as Morocco specified the spell of migration and the sector in the economy. Guestworkers were earmarked for low-level jobs in the industrial sector and manufacturing. Guestworkers contributed to the health of the labor markets and the economy of the host countries; the "German Economic Miracle" (Deutsches Wirtschaftswunder) in the 1960s is one example. Lastly, a lesser known circular labor migration scheme exists in oil-rich Arab countries. Massive guestworker migration to these countries occurred in the 1970s with the oil crises and has continued to this day. Guestworkers in these countries played a major role in the economic development and structural changes in oil-rich Arab countries.

The rational of the guestworker migration is that: (i) employers can satisfy their short-term excess demand for low skilled workers without having to increase wages. Hiring low-wage unskilled workers also guarantees a bottom in the hierarchy of jobs and wages and thus eliminates the need to increase anybody else's wages. This scheme ensures high profits to the employers, (ii) employers can recruit young, healthy, and brawny men for these jobs from a known and reliable pool of workers with the blessing of the workers' home countries, (iii) unskilled guestworkers are almost always substitutes of machines and complements of native workers, therefore they create no friction to the skilled native manpower, (iv) native workers are free to move up on the professional and socioeconomic ladder and receive extra training, (v) guestworkers contribute to the low-cost increased production of consumer goods - at relatively low 
prices, (vi) guestworkers as consumers increase demand for goods and can introduce new ethnic goods to the receiving country enriching the gamut of available goods, (vii) guestworkers pay taxes and contribute to the public coffers, (viii) the employers, under the auspices of their governments can always send these guestworkers back to their home when they do not need them; after all, these workers were meant to be guests and not stay forever, (vi) based on the temporary and circular character of these schemes politicians can pacify xenophobic interest groups and concerned laborers who may be substitutes to guestworkers without risking to lose their electorate.

The formation of migration networks and migration-specific capital helps to establish optimal matches between workers and employers. Besides economic benefits, another advantage from migration comes from the influx of mostly young, healthy, and productive workers who have a "rejuvenating effect” on aging societies.

From the sending countries' point of view circular migration programs are beneficial for the following reasons. The sending countries (i) are relieved from any unemployment frictions and labor market imbalances, (ii) benefit tremendously from the remittances that their emigrants send back; remittances can be monetary, or in-kind, (iii) gain from the new skills and knowledge that return migrants acquired abroad and bring with them upon return, (iv) through bilateral or multilateral agreements in migration, the sending countries may also strike additional agreements in trade and development and benefit even further from cooperation. It should be noted that these countries have usually lower levels of economic development and are characterized by masses of able and available laborers, low wages, scarce capital, and high interest rates.

Remittances are an integral part of migration and are resilient to any economic recession or the business cycle. This financial aid helps the individual recipients at the 
micro-level, as well as the governments at the macro-level. Remittances reduce poverty of families left back home, stimulate markets by increasing the demand for local goods and services (Bird and Deshingkar, 2009), reduce child labor ${ }^{7}$, contribute to investments in human capital, in development, and other productive assets such as enhanced infrastructure. Returnees invest and build up new enterprises in their home communities while maintaining non-family networks and highly productive linkages for trade and investment, as is the case for highly-skilled returnees. Circular migration returnees bring with them knowhow and a different way of doing things that can influence ideas. While their visits in each country are of a shorter time, they are offering updated information on the latest happenings in each country. Circular migrants are often conduits of technology, fashion, and news by their mere presence in the country. All these mechanisms are often cited as counter examples of "brain drain.”

Savvy migrants delve into circular movements because they can take advantage of better employment and payment opportunities in different countries through time. They are able to optimize and re-optimize their income, savings, and assets strategies and improve their economic, social and personal situation in every period (Constant and Zimmermann, 2011). They minimize their search, relocation, and psychic costs while generating a comparable advantage over non-migrants and one-time movers as they build up migration-specific knowledge and local-specific capital in both countries. Migrants are willing to accept low-paid jobs because they believe that these jobs are only temporary and for the short-term. On the other hand, these jobs pay more than what they would have earned in their home countries and thus, they can remit more and accumulate more wealth in a short time. Here we should note that there are a few programs of short-term repeated migration that are similar to guestworker programs, but 
for highly skilled IT and R\&D personnel. In the US these are H1-A and H1-B visa programs, and specific visiting programs in academia.

\section{2.b. Shortcomings in 3-Di}

In reality, the circular migration model has practical disadvantages and caveats. First, receiving countries may face grave compliance problems and illegal "overstaying” if migrants do not conform to the terms of the circular migration program and do not return to their homelands. However, even if guestworkers overstay under a legal status, the receiving countries suddenly face increased migration and have to provide for these individuals and their families. In reality, the circularity and short-term migration lullaby prevented the host countries from planning the long-term settlement of these workers or their families. In the event that migrant workers stay in the host country for good, there are often no provisions for their socioeconomic or educational integration. The worst scenario is that migrants stay in the host country - usually without the proper documentation - and they manage to bring their families in for long-term residence. This puts a huge strain on the cities and localities where immigrants settle. Primarily, overstayers and their families can cause financial burden on local schools and hospitals.

Germany is among the prominent examples of what happens when efforts to encourage return migration fail. After the recruitment ban in 1973 most of the guestworkers from non-EU countries did not return to their home countries as intended. ${ }^{8}$ Instead, they stayed in Germany, became permanent residents, and brought their family members to Germany in the course of family reunification and family building. In contrast, guestworkers from EU countries left Germany because they knew that they could go back to Germany to work any time they needed to. 
While in Germany and other continental EU countries illegal or undocumented migrants are not a big problem, it is one in the US and has immense ramification in everyday life and in politics. Clandestine migration and smuggling are very much affected by government interventions ${ }^{9}$ and often in a counter-intuitive way. Intensifying efforts to stop illegal entries, increasing raids, and stepping-up deportation policies may make illegal migrants more likely to stay as exploited workers underground rather than surfacing and facing deportation.

From the sending countries perspective, a mass out-migration of the working population can create grave labor market shortages. In the case of an exodus of highly educated individuals the sending countries can experience brain drain, at least in the short-run until the "brains" return. In addition, some authors refer to "reverse remittances," to describe the situation that remittances trigger in the home country. Remittances can have a negative impact on the labor force participation and productivity of migrants’ relatives and friends who receive them. Reverse remittances include services such as “raising the migrant’s children and managing housing construction and business, as well as services related to obtaining documents for regularizing a migrant's stay abroad and for ensuring their social security” (Mazzucato, 2009). Lastly, repeat migration can be seen as a way of comfortable living and can trigger further out-migration that may not be desirable to the sending or receiving countries.

As circular migrants often move on their own and leave their children with their families at home ${ }^{10}$, reverse remittances can be expected to be higher for them than for migrants who move with the entire family. Children living in "split families" where one or both parents migrate regularly may suffer from a lack of parental care which, in turn, 
may reduce their well-being and have negative consequences for their economic performance later in life. Poor governance of migration institutions may reduce the potential benefits of circular migration even further, such as financial support. Regarding the Chinese migration experience to North America and Australasia, one encounters the "astronaut” syndrome and the "parachute kid” syndrome (Skeldon, 1998) as vivid illustrations of transnationalism. The first syndrome conveys the case of the typical male astronaut migrant who returns home for business while leaving his family in the host country. In the parachute kid syndrome, the migrant parents return home while leaving their kids with relatives established in the host countries.

Probably even more severe are the costs to the circular migrants themselves, who can be victims of discrimination and xenophobic attitudes, as well as they bear the risk of exploitation due to lack of employment protection, and lack of integration opportunities. There is the possibility that circular migrants may remain trapped in lowpay menial jobs and need to continue their participation in guestworker programs if they target a certain amount of money and are used to a certain lifestyle; Mexican workers coming in the course of a Canadian guestworker program have displayed this feature (Basok, 2003).

Temporary migrants caught in unskilled and precarious jobs may also be exposed to various forms of abuse, discrimination, and exploitation which, as Amnesty International claims, can lead to a "modern form of slavery” (AI, 2000). Deshingkar and Start (2003) show that even though circulation is extremely prevalent in India with millions of (poor) laborers migrating for the best part of the year, Indian policymakers refuse to improve migrants’ situation. Accordingly, migrants have no entitlement to livelihood support systems or formal welfare schemes, and they are also refused full 
payment which is reduced even further because contractors deduct a good part of that as well. ${ }^{11}$ It is therefore the case that improved monetary prosperity comes at a high psychological cost born by the migrants. The psychological toll of being separated from their households, communities and cultures, can offset some of the material benefits accrued to the sending country (Basok, 2003).

Migrants, in general, can jeopardize their health through migration. Working hard in precarious jobs and without health insurance can erode the health of workers. It is even worse when circular migrants are parents who have left their children behind ${ }^{12}$. Their well-being may decline in the course of their absence from home with serious ramifications of their children's welfare. Circular migrants, whether legal or illegal tend to avoid hospitals and doctors. If they are legally working they may not have health insurance and may not afford to go to the doctor until the very last minute when they go to the emergency room. If they are undocumented, they never go to the doctor because they fear they might be arrested or deported. They only seek help when their illnesses become emergencies. Lastly, even when they seek health care, it is not always easy to be treated because of communication barriers as well as cultural barriers.

A largely understudied circular labor migration takes place with Saudi-Arabia that receives many guestworkers from poor non-oil-rich countries, as well as Thailand or Bangladesh. Labor migration to oil-rich Arab countries boomed in the 1970s with the oil crisis and has been continuing since then. Unfortunately, there are practically no data available to study this type of migration. Many Southern-Arabian economies rely heavily on a "sponsor system" that strips migrants of most of their rights; payment is low, migrants are unable to leave their work place without permission, and they are completely at the mercy of their employer who collects the migrant's passport upon 
arrival (Amnesty International, 2000). Migrants are forbidden to marry natives, to bring over their family, or to naturalize.

Even in the best of scenarios, circular migrants risk to be seen as transient, as "different" than the locals, and as outsiders who cannot belong to one community. This can start a downward spiral of the alienation of migrants. The pervasiveness of the temporary character of regulated circular migration can harm the migrants in the following way: if migrants are convinced that they are in the host country temporarily they will most likely not devote any efforts to become part of the new country's life, learn the language, invest in it, and/or naturalize.

Hence it is of outmost importance for programs managing circular migration to bring out the best economically, while guaranteeing humane livelihood conditions for people moving back-and-forth. The following section provides the empirical evidence of circular migration schemes.

\section{Evidence}

\subsection{Experiences from Labor Migration Restrictions}

As discussed in the previous section, circular migration can create a positive stimulation of labor markets in both the sending and the receiving country, but it can also lead to dependencies, discrimination and alienation. Social acceptance by the receiving country is a serious issue. Many societies are worried about "foreign infiltration” due to increased immigration. However, simply restricting circular migration is not a solution and often has quite the opposite effect as the following examples will illustrate.

Before the elimination of the bracero migration in 1964, Mexican workers were free to move between Mexico and the U.S., three states in particular: California Illinois, 
and Texas. ${ }^{13}$ Mexican laborers commuting for employment purposes to the US on a regular basis used to enjoy free labor mobility until an (initially benevolent) change in legislation ended this privilege. This change in legislation resulted in severe restrictions such as immigration quotas and enhanced border control for laborers coming from Mexico who sought work in the U.S. This led to major changes in the structure and pattern of migration as Massey (2011) discusses comprehensively.

The change in the American legislation and the emphasis on the US-Mexican border resulted in changing the geography of migration, and in having more Mexican families settling permanently in the US. The militarization of the border induced enormous costs on America's society and increased the costs and risks for Mexicans. Rendering border crossing so much more difficult, dangerous, and expensive has not stopped unauthorized Mexicans from coming to the US. It has on the other hand made "coyotes" richer, resulted in thousands of deaths, and kept Mexicans inside the wall, as back-and-forth migration was no longer an option. From his 30 year experience in studying Mexican migrants in the US, Massey (2011) has shown that before any US intervention Mexican migrants would return to Mexico after the harvest in the US. Currently, they stay and settle in living in the US in poverty while they also put strains on the cities they are in. Instead of returning home to "live" and going back to the US to "work" Mexicans reunited with their families in the US where many live for years in the shadows, while they raise American children.

While in the early 1980s the average Mexican worker (usually undocumented) was staying in the US for about three years, by the late 1990s, the average stay was nine years. Responding to raids and militarization of the US-Mexican border, Mexican 
migrants stop going home and brought their families in the US, where we see a tremendous growth of the Mexican population with about 12 million undocumented.

Since the 1990s, and especially after 9/11 anti-Hispanic hate crimes have increased. "The demonization of Mexican immigrants set off a chain reaction that ultimately yielded a massive increase in both border and internal enforcement, which transformed the circularity, demography, and geography of Mexico-U.S. migration” (Massey, 2011). While the de jure labor system in the US was based on the annual circulation of legal temporary workers and a small number of legal permanent residents, the recently brought on migration cap changed the system to a de facto system of yearly circulation of undocumented workers and a rather larger number of permanent residents (Massey, 2011).

German history offers yet two more examples of failed attempts to manage circular migration and to redirect migration flows. The first is the guestworker program during Germany’s extraordinarily fast economic growth (Deutsches Wirtschaftswunder) in the late 1950s and in particular early 1960s that made the need for imported cheap labor imperative. In response, Germany signed bi-lateral treaties for recruitment of blue collar workers in low qualified sectors with several Southern European states like Spain, Italy, Greece, Turkey, and Yugoslavia. This was a demand-driven and project-tied immigration system. The system was successful in recruiting the desperately needed laborers, who worked hard and contributed to Germany's economic boom. However, the first oil crisis in 1973 prompted the German government to stop its active recruitment of low skilled workers (see Zimmermann, 1996; Constant et al., 2012). Subsequent efforts to encourage and plans to achieve return migration failed and quite the contrary 
occurred. Germany experienced an increase of its guestworker population due to family reunification in Germany and high fertility rates of these families in Germany.

Migration may erode institutional constraints (Zimmermann, 1996). Even though many European countries that once actively recruited labor migrants turned to restrictive policies afterwards, they were unable to find successful policy instruments and incentives that materialize and enforce return migration. Migrants from non-EU member countries, such as Turkey and the former Yugoslavia who did not have the option to easily return to Germany for work in the event of an upswing of the business cycle, often stayed and became permanent residents. Interestingly and paradoxically, labor migrants from EU-member states such as Italy or Spain who could re-enter and work in Germany at any desired period returned to their homelands more often (Constant and Zimmermann, 2011). ${ }^{14}$ The increase of the Turkish population in the 1980s after four rounds of incentives to leave is a testimony to backfired policymaking with ensuing increased social tension between native and foreign population groups The US and German paradigms concur that - as odd as it sounds - free labor mobility decreases migration and constrained or forbidden migration results in increased numbers of permanent migrants.

Based on negative experiences after the recruitment ban Germany’s government became very cautious regarding the EU East-Enlargements in 2004 and 2007. Like Austria, Germany opted against free labor mobility from the new member states for a seven years transition period. Fears of mass migration, of "welfare tourism” and of displacement effects in the labor market kept the German doors closed, but not without repercussions. ${ }^{15}$ As a result, the best qualified workers from the new states went to other EU countries. For example, skilled workers from Poland preferred to go to the United 
Kingdom or Ireland - states that did not restrict immigration at all. It was the less qualified from the EU-8 who entered Germany under legal exceptions counteracting Germany’s protective immigration politics. ${ }^{16}$ These less skilled workers compete with the other non-EU migrants who live in Germany. Once more, restrictive immigration policies backfired and led to the opposite of the desired outcome. In fact, the closeddoor policy not only failed to attract the so-much needed high-skilled workers, but it was also unable to avoid the attraction of low-skilled immigrants

\subsection{Empirical Findings: Who Are the Circular Migrants?}

Knowing the characteristics of circular migrants is a powerful and successful tool of migration policy. Following their self-interests sovereign governments can decide to which migrants permit entry. Empirical evidence on circular migrants is scarce since not many countries have records on the entry and exit of their residents. It is even rarer to record temporary moves such as those in circular movements. Even when reliable data on entry and exit exist migration studies suffer from selection biases. Some knowledge exists regarding internal migration, that is, migration within a country or close region. For instance there are available studies for the US (DaVanzo, 1983), Africa (Beguy et al., 2010; Bigsten, $1996^{17}$ ), India (Deshingkar and Start, 2003), and the Asia-Pacific region (Hugo, 2008, 2009; Lidgard and Gilson, 2002).

Massey and his collaborators have been studying the behavior of Mexican migrants to the US for many decades and have offered tremendous insights in circular or repeat migration. The series of trips to the US is determined by the migrant experience, while social networks also play an important role in undertaking an additional trip (Massey, 1987). Conditional on having one trip already, the odds of 
taking an additional trip to the U.S. for both documented and undocumented migrants increase with experience, occupational achievement, and social capital (Massey and Espinosa, 1997). The leitmotif of these studies is that the characteristics for circular migration are different than the characteristics of an initial migration. A study on the migration past of new permanent residents in the US showed that 32 percent of them had a previous illegal experience (Jasso et al., 2008). Out of them, 19 percent had entered without inspection, 12 percent had visa overstay experience, and 11 percent have had unauthorized jobs. The authors find that in the movement from illegal to legal some immigrants experienced substantial upward social mobility.

While there are nascent empirical studies in Asia, circular migration is of a much higher order. A recent study about Thailand and its circular or repeat migrants to six major destination countries (Taiwan, Hong Kong, Israel, Brunei, Singapore, and South Korea) concurs that circular migrants are a highly selected group (Lee et al., 2011). These circular Thai migrants are more likely to be males, less likely to send remittances, and more likely to save - compared with first-time migrants. Circular migration exhibits a strong correlation with age and follows an inverted U-shape. Interestingly, Hugo (2009) finds that circular migrants in Asia remit more money than permanent emigrants.

For the Pacific region, Gibson and McKenzie (2011) are able to study emigration and return migration among the very highly skilled. Based on a unique survey about the best and brightest academic performers from Tonga, Papua New Guinea, and New Zealand the authors find that emigration is most strongly linked with risk aversion, patience, and choice of subjects in secondary school. Paradoxically, the gain in income from migrating is not a significant determinant. The decision to return is strongly associated to family and lifestyle reasons, rather than to the income 
opportunities in different countries. The authors conclude that income maximization has a very limited role in migration decisions among the very highly skilled.

For Europe little is known about circular movements per se, except for pioneer work by Constant and Zimmermann (2003, 2003a, 2011, and 2012) on circular immigrants in Germany. The existing related literature studies return and out-migration for Germany (Constant and Massey, 2003), The Netherlands (Bijwaard, 2010), Denmark (Jensen and Pedersen, 2007), and Sweden (Nekby, 2006). All studies confirm the highly selective nature of circular migration. From a migrant sending country's perspective, Vadean and Piracha (2010) as well as de Coulon and Piracha (2003) study out-migration and return patterns of Albanian laborers going to geographically close regions in Greece and Italy. Most of these studies actively support the assumption that circular migration is primarily labor migration. ${ }^{18}$

Taking advantage of particularly rich, representative and longitudinal data from the German Socio Economic Panel (GSOEP) Constant and Zimmermann (2011) study circular migration patterns of former guestworkers in Germany. Specifically, they analyze the number of exits and the total number of years away from the host country. They find notable circular movements with about 60 percent of Germany’s immigrant population being circular movers. The authors identify some interesting characteristics of circular migrants.

Namely, migrants from other EU member countries who usually face fewer - if any -institutional hurdles when they want to return to Germany are more frequent circular migrants. Those who do not own a dwelling in Germany, the younger and the older individuals (excluding the middle-aged), are significantly more likely to engage in repeat migration and to stay out of Germany for longer. Males are more likely to engage 
in exit and entry than females. Migrants with German passports exit Germany more frequently, demonstrating that possession of the German citizenship induces outmigration. Specifically, migrants from Italy, Greece, or Spain - hence migrants coming from one of the three former guestworker countries that are now EU-member states and migrants who have gained German citizenship exit Germany more frequently than migrants coming from Turkey or the former Yugoslavia who face more legal restrictions upon returning to Germany. Turks and Yugoslavs are thus less mobile; they exit fewer times and spend substantially less years out of Germany.

The same study finds that, as expected, migrants who are closely attached to the labor market in Germany remain less time outside and are leaving (exiting) the country less frequently. In contrast, when family is left back in the home country this definitely elongates the time circular migrants spent out of Germany. Migrants with higher education exit less often and there are no differences with time spent out of Germany. Interestingly, vocational training - an important feature of the German educational system - does not play a significant role in the international mobility decision. This is in contrast with findings from New Zealand (Lidgard and Gilson, 2002) and The Netherlands (Bijwaard, 2010). In fact, labor migrants from Western countries who are usually better educated show higher mobility rates than labor migrants from countries that are more distant with respect to both geography and culture (Bijwaard, 2010). ${ }^{19}$

Another study on migrants in Germany using a dynamic Markov modeling approach identifies factors generating single moves, circular migration, and absorption states from the first 14 individual years of GSOEP (Constant and Zimmermann, 2012). Newcomers are more likely to leave shortly after their arrival and when they have social and familial bonds with the home country. Conversely, migrants are less likely to leave 
Germany when they have a job and speak the German language well. After exiting Germany the probability to return is influenced by remittances and family considerations. Circular migration, in particular, is significantly fostered by vocational training acquired in Germany and by older age. While men are more likely to return to the home country, gender is not significant in predicting the re-return to Germany after an exit.

According to the Constant and Zimmermann (2012) study, the annual probability of immigrants to leave Germany is low, about 10 percent, but once they are in their home country the likelihood of undertaking a repeat move and returning back to Germany is high, about 80 percent of the observed transitions. They further report lifetime simulations with the estimated models to study the dynamic process. These exercises show that while the probability to return to the home country remains low as time elapses, the probability to return back to Germany from the home country is high and approaches 1 , the older the immigrants are and the earlier they have migrated for the first time to Germany. This suggests that the remaining repeat migrants are indeed migrant workers, who come to Germany to earn money, but that there is no evidence that they finally attempt to return to the home country. To the contrary, Germany remains the magnet and will eventually become their real home country.

These findings are confirmed by various studies for other countries such as Sweden, where repeat migrants are mostly of Nordic origin, male, single, between the ages of 36 and 55, and migrate to Sweden for work-related reasons (Nekby, 2006). Similarly, Lidgard and Gilson (2002) report that circular migration of New Zealand nationals is most common among single individuals and those aged around 30. For New 
Zealand nationals, however, non-economic reasons are as important as economic factors for their return from Australia and the US.

Other studies show similar migration patterns in Denmark, a country that experienced analogous migration to Germany in the past. The Danish government recruited many guestworkers in the 1950s and 1960s, mainly from Yugoslavia, Pakistan, and Turkey, to satisfy labor market demand (Jensen and Pedersen, 2007). Comparable to situations in Germany and The Netherlands, coming from a high-income country increased the likelihood to leave Denmark. Coming from less developed countries, in particular from Pakistan and Turkey, exhibited much lower levels of return. This creates a paradox where immigrants who are assimilable or who for all practical purposes are integrated in the labor market are more likely to leave the host country, but those who face the most challenges to integration do not leave the host country (Jensen and Pedersen, 2007). Still, economic success and attachment to the labor market, as indicated by labor market experience in Denmark, have a positive impact on the propensity to stay.

Concurring findings exist for Albanian returnees, although Albania is a migrant sending and not migrant receiving country like Germany. Vadean and Piracha (2010) find that circular migrants are negatively selected from the pool of returning migrants with regard to education. Accordingly, among those who return to Albania, the least educated engage in repeat migration while the better educated re-enter the Albanian labor market. As for other countries, circular migrants are mostly men and, on average, younger than non-migrants; they are often members of poor and relatively large families, have only primary education, and come from rural and less developed areas close to Albania’s neighboring countries Greece and Italy. However, the better educated 
Albanians are more likely to migrate to other Western European countries, the US, and Canada. These better skilled individuals often migrate permanently, and do not return to Albania.

Employing MMP data, Reyes (1997) sketches the portrait of return Mexican migrants and comes to similar results; return rates are especially high for males, Mexicans with low education, low-wage earners, and for undocumented immigrants. Even more importantly, he finds that those who move once are very likely to move again and, thus, engage in repeat migration.

In summary, studies show that circular migration is mostly seasonal labor migration. It is most prevalent among the young, among men, and among the single. Attachment to the host country as indicated by owning a dwelling or being married and having family in the host country reduces the likelihood to circulate. In contrast, the acquisition of the host country's citizenship fosters circularity. Hence, the likelihood of a circular migration pattern arises with the freedom to leave and with the right to return (Constant and Zimmermann, 2011, p. 511).

\section{Recent Circular Programs and Policy Advice}

Many governments and governmental institutions consider to an increasing degree setting up programs that aim to manage circular movement of laborers in order to take advantage of the benefits associated with circular movement. The Commission of the European Communities (COM, 2007) for instance, has listed numerous ongoing and planned circular migration and mobility partnerships between the EU and third countries. Complementing this list, Newland et al. (2008) provide a broad overview of 
initiatives worldwide differentiated by type of migration: seasonal, non-seasonal, and circular movement of professionals, academics, and entrepreneurs.

Among the successful programs listed by the European Commission are partnerships signed by Spain with Morocco, with Colombia, and with Romania. While other countries were touched by mild recessions in the early 2000s, Spain followed a remarkable economic boom. Spain needed migrants for many sectors and different periods and delved into circular migration agreements, cautiously designed to have a carrot and a stick. The Programme de gestion integral de l`immigration saisonnière, for example, aims at implementing a system for the management of seasonal migration of Moroccan workers to Spain for strawberry and citrus fruit cultivation. Its objectives are, among others, to develop legal immigration for temporary jobs, to prevent illegal practices, and to guarantee the return after the season. Preventing irregular migration is also one of the aims of the "Temporary and circular labour migration” (TCLM) project between Colombia and Spain, a program implemented by the International Organization for Migration (IOM). The remarkable success of circular migration programs in Spain ${ }^{20}$ ended with the world-wide recession of 2008. The programs will now have to demonstrate that they also operate as expected at the downside oft the business cycle.

There are also programs focusing on South-South migration rather than migration into the European Union. One such program, the "Management of labour migration as an instrument for development” is implemented in Africa by the International Labour Organization (ILO). The ILO also promotes the “Asian Programme of the Governance of Labour Migration” that targets countries such as China, Korea, and Japan. One of its aims is to "minimize exploitation and abusive 
treatment by encouraging active dialog and cooperation among countries in the Asian region” (COM, 2007). Protecting migrant workers’ rights and reducing bureaucratic obstacles to recruitment are also among the aims of the "Towards sustainable partnerships for the effective governance of labour migration in the Russian Federation, the Caucasus and Central Asia” project. As the name indicates, this is a cooperation agreement between the governments of the Russian Federation, Armenia, Kazakhstan, Kyrgyzstan and Tajikistan. ${ }^{21}$

Newland et al. (2008) provide a detailed list of: seasonal worker programs between Canada and Mexico, the "Seasonal Agricultural Workers Program” (SAWP), and Canada’s new initiative, the “Low-Skilled Pilot Project”; agreements between Spain and "foreign workers who do not enjoy free circulation within the EU labor market” in addition to Spain's bilateral agreements with Colombia, Ecuador, and Morocco; the Dominican Republic, Poland and Romania; Bulgaria; Mauretania and Senegal; Cape Verde; with Gambia, and Guinea and Mali; They describe New Zealand's new “program for seasonal workers from the Pacific islands”, the United Kingdom’s “Seasonal Agricultural Workers Scheme” and its "Sector Based (point) Scheme” (SBS), as well as the H-2B and H1-B visa program of the US.

This exemplary documentation demonstrates that there is a huge variety of projects and programs aiming to manage circular labor movements in various countries worldwide. The complexity in setting up such programs lies in the different requirements and priorities of sending and receiving countries, as well as in migrants’ needs, anxieties of members of the host society and worries of family members staying back home. Designing a system that takes into consideration all these needs and necessities at the same time is not trivial. 
Nonetheless it is useful to promote a catalogue of measures that should be considered when setting up programs to encourage circularity (Newland et al., 2008; Zimmermann, 2009, Constant and Zimmermann, 2011). The successful policy agenda of circular migration should include, for example, the free access of immigrants to the global labor market. However, this policy agenda should connect a migratory move to a job generated from the market system, thus rendering the labor market the filter for migration. The right to enter a country and the requirement to leave it should be linked to the availability of work. The basic principle of circular migration should be the right or the chance to return back to the host country and should even offer rewards to those return migrants who honored the return migration code. International standard settings should include giving minimum work contract standards, providing the means to preserve pension rights, facilitating the free circulation of remittances, and enabling the reunion of family members. Further, governments (i) need to find instruments that improve the fit between employers and migrants; (ii) need to provide channels through which entitlements, such as pensions, that migrants build up during their stay and work abroad can be transferred easily; and (iii) need to offer possibilities for upward mobility by providing training for skill upgrading.

Angenendt (2009) draws four conclusions from the circular migration debate which could also be important elements in a circular migration policy bill. First, circular migration programs should be realistic and transparent, meaning that they should contain provisions for every contingency even for illegal or irregular migrants, which are bound to happen. Above all, circular policies should secure the human rights of migrants. Second, a successful policy bill should have clear and unambiguous goals, and third, it should be tailored to skill levels. Lastly, the agents involved in this 
should be aware that the success of these programs requires substantial governance efforts.

Furthermore, migrants should be able to easily gather information about possibilities and risks of working abroad as well as about safe travel routes and migration channels. Conditions that try to "enforce" circularity, for instance by offering only very short-term contracts and non-renewable visas or visas that are tied to particular employers without the option to switch to other admission categories will increase the risk that migrants refuse to conform to the terms of circular migration programs. In contrast, they are more likely to engage in illegal and unauthorized migration. Hence, it is most important to remove obstacles and to encourage circular movement by simplifying bureaucracy and red tape and by making programs more flexible. Often programs are too slow to respond to employers’ needs and market conditions (Newland et al., 2008).

To promote high-skilled circular migration - as is often desired by governments the receiving and sending countries have to work together and for the longer-run. Migration and circulation of people is more complex than the international trade for goods. Examples of bi-lateral cooperation concern the setting up of service centers that offer housing assistance to returnees, as is the case in China, or the loosening of their foreign-currency exchange controls, like India does. Agreements between Germany and Turkey include educational support to the children of returnees who do not speak the Turkish language and need to integrate in Turkey. The IOM implemented a “return-of-talents” program in Africa, Latin America, Afghanistan, and Sudan that offers recruitment, job placement, transport, and some employment support. Dual citizenship and voting rights are complementary instruments that can bind expatriates 
to their home country. Through these channels, migrants maintain personal and political attachment with both the sending and receiving country and keep in touch with their home communities. To intensify the attachment with the origin, the UN subsidizes volunteer professionals who return to the home country on a short-term basis to pass on skills and knowledge that they acquired abroad. The most successful programs balance push and pull factors and gently navigate circular movements.

\section{Conclusions}

The “once and forever” migration moving strategy is passé; circular migration is considerable and highly selective. Circular migration is pivotal in assessing the relative success of immigrants in the host country labor market as well as in measuring the economic impact of immigration, with serious fiscal implications. Understanding circular migration patterns and gaining knowledge about circular migrants is very important. Research on circular/repeat migration can improve the ability to forecast trends in immigration and to design a better migration policy. The increasing number of studies dealing with circular migration and burgeoning circular migration agreements among countries are indicative of this. Circular migration is widely perceived as possessing the possibility to generate benefits for sending and receiving countries as well as for the migrants themselves.

Circular labor migration is the best tool for labor economists who contemplate about successful labor market and migration policies. By its mere definition it is not permanent, and if managed properly, it can accommodate volatile labor markets best. Circular migration is the ideal solution to filling labor market shortages through time. 
Even though empirical evidence is rare, existing studies show that circular migration is most common among the young, among men, and among those who do not show a strong commitment to the host country. Contradicting common beliefs and intuition, naturalization and acquisition of the host country's citizenship does not bind nor immobilize immigrants. Instead, it provides immigrants with freedom of re-entry and thus encourages out-migration. In fact, the easier and more facile mobility is, the more likely are migrants to engage in and practice repeat and circular migration (Constant and Zimmermann, 2011, p. 513).

For governments planning to establish circular migration systems it is important to find ways to bring out the benefits while mitigating negative side effects such as exploitation and disadvantageous dependences. However, intervening in labor mobility, restricting back-and-forth movement, and coercing immigrants to return to their homelands will not serve the purpose as various historical experiments have demonstrated. Migration restrictions often backfired, and tight and restrictive policy measures appeared to be counter-productive. From that experience, circular migration resulting from free labor mobility filtered by the availability of jobs in the host countries could work better.

Governments can encourage circularity by offering incentives such as possibilities for upward mobility and training as well as portability of benefits across countries. Furthermore, repeat migration can be fostered by incentives given in the source countries. "Diaspora” policies linking the ethnic networks in receiving countries to the countries of origin is another approach with potential. ${ }^{22}$ Still, circular migration may not be "a silver bullet” to every problem; for example, skills learned in 
developed economies may not be transferable to circumstances and realities in the developing world (Skeldon, 2010).

It is clear that migration policies cannot be successful when applied unilaterally. Receiving and sending countries should be working together if they want to reach a beneficial goal. Migration in general and circular migration in particular cannot be viewed in isolation, but as part of a general foreign policy. International trade, economic development, environmental changes, technological advances, and any kind of abrupt shocks are all interrelated and linked to migration.

Despite the gain in insight as discussed in this article, many questions are still unanswered. For instance, the effects of circular migration on economic factors such as output, wages, or unemployment rates, or on "soft” factors such as integration, ethnic identification, or individual well-being are still unclear. Consequently, more research is needed on this topic in order to completely understand driving factors, benefits, and shortcomings of circular movement. Only when determinants and consequences are much better understood, can regulated systems be established to have a chance to manage circular migration more successfully. 


\section{References}

Angenendt, S. (2009), 'Labor Migration Management in Times of Recession: Is Circular Migration a Solution', Transatlantic Academy Paper Series, The German Marshall Fund of the United States, Washington D.C.

Basok, T. (2003), 'Mexican seasonal migration to Canada and development: A community-based comparison’, International Migration, 41 (2), 3-26.

Bigsten, A. (1996), 'The Circular Migration of Smallholders in Kenya’, Journal of African Economics, 5 (1), 1-20.

Bijwaard, G. E. (2010), 'Immigrant migration dynamics model for the Netherlands', Journal of Population Economics, 23 (4), 1213-1247.

Bird, K. and P. Deshingkar (2009), 'Circular Migration in India’, Policy Brief No. 4, prepared for the World Development Report 2009.

Bonin, H., W. Eichhorst, C. Florman, M. O. Hansen, L. Skiöld, J. Stuhler, K.

Tatsiramos, H. Thomasen and K. F. Zimmermann (2008), 'Geographic Mobility in the European Union: Optimising its Economic and Social Benefits’, Joint expertise with NIRAS Consultants and AMS for the European Commission, IZA Report No. 19, Bonn: Institute for the Study of Labor (IZA. 
Brenke, K., M. Yuksel and K. F. Zimmermann (2009), ‘EU Enlargement under Continued Mobility Restrictions: Consequences for the German Labor Market', in Martin Kahanec and Klaus F. Zimmermann (eds), EU Labor Markets after PostEnlargement Migration, Berlin, et al.: Springer-Verlag, pp. 111-129.

Castles, S. (2006), ‘Guestworkers in Europe: A Resurrection?’, International Migration Review, 40 (4), 741-766.

Chan, K. W. and L. Zhang (1999), 'The Hukou System and Rural-Urban Migration in China: Processes and Changes’, The China Quarterly, 160, 818-855.

COM (2007), On circular migration and mobility partnership between the European Union and third countries. Communication from the Commission to the European Parliament, the Council, the European Economic and Social Committee and the Committee of the regions, Brussels, COM (2007) 248 final.

Constant, A. and D. S. Massey (2003), 'Self-Selection, Earnings, and Out-Migration: A Longitudinal Study of Immigrants to Germany’, Journal of Population Economics, 16 (4), 631-653.

Constant, A. F., O. Nottmeyer and K. F. Zimmermann (2012), 'Cultural Integration in Germany’, in: Yann Algan, Alberto Bisin, Alan Manning and Thierry Verdier (eds), Cultural Integration in Europe, Oxford: Oxford University Press. 
Constant, A. F. and K. F. Zimmermann (2003), 'Circular Movements and Time Away from the Host Country’, IZA Discussion Paper 960, Bonn: Institute for the Study of Labor (IZA.

Constant, A. F. and K. F. Zimmermann (2003a), 'The Dynamics of Repeat Migration: A Markov Chain Analysis', IZA Discussion Paper 885, Bonn: Institute for the Study of Labor (IZA).

Constant, A. F. and K. F. Zimmermann (2011), 'Circular and Repeat Migration: Counts of Exits and Years Away from the Host Country’, Population Research and Policy Review, 30 (4), 495-515.

Constant, A. F. and K. F. Zimmermann (2012), 'The Dynamics of Repeat Migration: A Markov Chain Analysis’, International Migration Review, 46 (2), 361-387.

DaVanzo, J. (1983), 'Repeat Migration in the United States: Who Moves Back and Who Moves On?', The Review of Economics and Statistics, 65, 552-559.

De Coulon, A. and M. Piracha (2003), 'Self-selection and the performance of return migrants: the source country perspective', Journal of Population Economics, 18 (4), 779-807. 
Deshingkar, P. and D. Start (2003), ‘Seasonal Migration for Livelihoods in India: Coping, Accumulation and Exclusion', Odi Working Paper 220, Overseas Development Institute, London.

Dierx, A. (1988), ‘A Life-Cycle Model of Repeat Migration, Regional Science and Urban Economics', 18, 383-397.

Fargues, P. (2008), 'Circular Migration: Is it Relevant for the South and East of the Mediterranean?’, CARIM Analytic and Synthetic Notes 2008/40, Circular Migration Series, European University Institute, Robert Schuman Centre for Advanced Studies.

Gibson, J. and D. McKenzie (2011), 'The Microeconomic Determinants of Emigration and Return Migration of the Best and Brightest: Evidence from the Pacific', Journal of Development Economics, 95 (1), 18-29.

Giulietti, C., M. Guzi, M. Kahanec and K. F. Zimmermann (2013), 'Unemployment Benefits and Immigration: Evidence from the EU', International Journal of Manpower, 34 (1/2), forthcoming.

Hugo, G. (2008), 'In and out of Australia: Rethinking Chinese and Indian Skilled Migration to Australia', Asian Population Studies, 4 (3), 267-292.

Hugo, Graeme J. (2009), ‘Circular Migration and Development: An Asia-Pacific Perspective’, in: Ondrej Hofirek, Radka Klvanova and Michal Nekorjak (eds), 
Boundaries in Motion: Rethinking Contemporary Migration Events, Brno, Czech Republic: Centre for the Study of Democracy and Culture (CDK), pp. 165-190.

Jasso, G., D.S. Massey, M. R. Rosenzweig and J. P. Smith (2008), 'From Illegal to Legal: Estimating Previous Illegal Experience among New Legal Immigrants to the United States', The International Migration Review, 42 (4), 803-843.

Jensen, P. and P. J. Pedersen (2007), 'To stay or not to stay? Out-migration of immigrants from Denmark’, International Migration, 45 (5), 87-113.

Kahanec, M. and K. F. Zimmermann (eds) (2009), EU Labor Markets after PostEnlargement Migration, Berlin et al.: Springer-Verlag.

Lidgard, J. and C. Gilson (2002), 'Return Migration of New Zealanders: Shuttle and Circular Migrants’, New Zealand Population Review, 28 (1), 99-128.

Lee, S-H., N. Sukrakarn and J.-Y. Choi (2011), 'Repeat Migration and Remittances: Evidence from Thai Migrant Workers’, Journal of Asian Economics, 22 (1), 142-151.

Machin, S., P. Pekonen and K. G. Salvanes (2012), 'Education and Mobility’, Journal of the European Economic Association, 10 (2), 417-450.

Massey, D. S. (1987), 'Understanding Mexican Migration to the United States’, American Journal of Sociology, 92 (6), 1372-1403. 
Massey, D. S. (2011), 'Chain Reaction: The Causes and Consequences of America’s War on Immigrants', Keynote presented at the $8^{\text {th }}$ IZA $A M^{2}$ and $3^{\text {rd }}$ Migration Topic Week.

Massey, D. S. and K. E. Espinosa (1997), 'What’s Driving Mexico-U.S. Migration? A Theoretical, Empirical, and Policy Analysis’, American Journal of Sociology, 102 (4), 939-999.

Massey, Douglas S., Jorge Durand and Nolan J. Malone (2002), Beyond Smoke and Mirrors: Mexican Immigration in an Era of Economic Integration, New York: Russell Sage Foundation.

Mazzucato, Valtentina (2009), 'The development potential of circular migration: Can circular migration serve the interests of countries of origin and destination?', in Labor Migration and its Development Potential in the Age of Mobility, Round table theme 2: Circular migration, se2009.eu.

McCann, P., J. Poot and L. Sanderson (2010), 'Migration, Relationship Capital and International Travel: Theory and Evidence', Journal of Economic Geography, 10 (3), 361-387.

Nekby, L. (2006), ‘The Emigration of Immigrants, Return vs Onward Migration: Evidence from Sweden', Journal of Population Economics, 19 (2), 197-226. 
Newland, K. K., D. R. Agunias and A. Terrazas (2008), 'Learning by doing:

Experiences of Circular Migration', mpi-Insight, Washington D. C.: Migration Policy Institute (MPI).

Reyes, B. (1997), 'Dynamics of Immigration: Return Migration to Western Mexico’, Public Policy Institute of California, San Francisco, CA.

Schöni, D. (2000), ‘Moderne Sklaven’, AI Journal, retrieved from:

http://www.amnesty.de/umleitung/2000/deu05/312?lang=de\&mimetype=text/html.

Skeldon, R. (1998), 'Migration from China’, Journal of International Affairs, 46 (2), 434-455.

Skeldon, R. (2010), 'Managing Migration for Development: Is Circular Migration the Answer?', The Whitehead Journal of Diplomacy and International Relations, 11 (1), 21-33.

Thom, K. (2010), ‘Repeated Circular Migration: Theory and Evidence from Undocumented Migrants’, Mimeo, New York University.

Vadean, Florin and Matloob Piracha (2010), 'Circular Migration or Permanent Return: What determines different forms of migration?', in Gil S. Epstein and Ira N. Gang (eds), 
Migration and Culture, Frontiers of Economics and Globalization, 8, Bingley: Emerald Group Publishing Limited, 467-495.

Wang, F. L. (2004), ‘Reformed Migration Control and New Targeted People: China’s Hukou System in the 2000s’, The China Quarterly, 177, 115-132.

Zaiceva, A. and K. F. Zimmermann (2008), 'Scale, Diversity, and Determinants of Labour Migration in Europe', Oxford Review of Economic Policy, 24 (3), 428-452.

Zapata-Barrero, R., R. F. Garcia and E. Sánchez-Montijano (2012), ‘Circular Temporary Labour Migration: Reassessing Established Public Policies’, International Journal of Population Research, doi: 10.1155/2012/498158.

Zimmermann, K. F. (1996), 'European Migration: Push and Pull’, Supplement to The World Bank Economic Review and The World Bank Research Observer, 10 (1995), 313-342. Reprinted in: International Regional Science Review, 19 (1996), 95-128; Klaus F. Zimmermann and Thomas Bauer (2002) (eds), The Economics of Migration, Cheltenham: Edward Elgar Publishing Ltd., Vol. I, Part I, pp. 70-99.

Zimmermann, Klaus F. (2009), ‘Towards a Circular Migration Regime’, in: Labor Migration and its Development Potential in the Age of Mobility, Round table theme 2: Circular migration, se2009.eu. 
Zimmermann, Klaus F. and A. F. Constant (eds.), International Handbook on the Economics of Migration, Cheltenham: Edward Elgar Publishing Ltd., forthcoming 2013. 
${ }^{1}$ In this chapter, we do not discuss a formal theoretical model of circular migration. For relevant theoretical contributions we refer to Dierx (1988), Constant and Zimmermann (2012), Thom (2010) and the chapter of Kennan and Walker on Modeling Individual Migration Decisions in Zimmermann and Constant, forthcoming 2013.

${ }^{2}$ However, unlike what intuition dictates, circular movements among the members of the EU states in practice are rather limited; it is as if freedom to move immobilizes individuals. For an overview of the European determinants of immobility see Bonin et al. (2008). The migrant workers from the new member states after EU enlargement are an exception so far, see Zaiceva and Zimmermann (2008) and various chapters in Kahanec and Zimmermann (2009).

${ }^{3}$ An exception we find in the Scandinavian countries where some information about exit is potentially available through the public registers.

${ }^{4}$ This could be either frequent moves from the country of origin or a particular host country as the basis. Some studies investigate situations where migrants frequently move home from one host country (Germany; Constant and Zimmermann, 2011 and 2012) or to one home country (New Zealand; McCann et al., 2010).

\footnotetext{
${ }^{5}$ More information about the "bracero" program can be found in Massey (2011). The European “guestworker” programs are studied by Castles (2006) and Zimmermann (1996). A comprehensive list of regulated programs between the European Union and third countries can be found in COM (2007), for example. An exemplary abstract of these projects is also discussed in section 4.

${ }^{6}$ See again Castles (2006) and Zimmermann (1996) for further information.

${ }^{7}$ See the chapter on Independent Child Labor Migrants by Edmonds and Shrestha (forthcoming in 2013).

${ }^{8}$ The myth that most of the guestworkers did not go home other than planned is, however, not generally true. Most of the guestworkers went home as originally planned. However, some groups stayed and brought intensively family. Zimmermann (1996) has studied the broader picture.
} 
${ }^{9}$ See the chapter by Friebel and Guriec on Human Smuggling (forthcoming in 2013).

${ }^{10}$ The chapter by Antman (forthcoming in 2013) provides an elaborated survey of the new research on the impact of migration on family left behind.

${ }^{11}$ See also Newland et al. (2008) for a detailed description of the Canadian Seasonal Agricultural Workers Program (SWAP), as well as work programs in Spain, New Zealand, Germany, the United Kingdom and the United States.

${ }^{12}$ See the chapter by Antman (forthcoming in 2013) for further discussion.

${ }^{13}$ For further information see Massey (2011), Massey and Espinoza (1997), and Massey et al. (2004).

${ }^{14}$ Other European countries like France, Denmark and The Netherlands experienced similar changes in their immigrant population whereby those leaving had the option to re-enter easily. See e.g. Jensen and Pedersen (2007) for out-migration of immigrants from Denmark, and Bijwaard (2010) who studies immigration migration dynamics models for The Netherlands.

${ }^{15}$ Such fears were unjustified as research on the effects of enlargement on the EU labor markets (see Kahanec and Zimmermann, 2009) and on the European welfare magnet (Giulietti et al., 2013) has shown.

${ }^{16}$ See Brenke, Yuksel and Zimmermann (2009) for a detailed discussion of Germany’s reaction to EU East-Enlargement.

${ }^{17}$ Bigsten (1996) is interesting since it treats not the individual but the household as the decision unit and investigates circular migration of farm household members in Kenya.

${ }^{18}$ Except for New Zealand nationals for whom non-economic reasons play a similarly important role as economic issues (see Lidgard and Gilson, 2002), employment purposes are among the most pressing reasons for migration. They predominantly migrate for educational reasons. In contrast, Vadean and Piracha (2010) show explicitly that employment purpose is the main reason for migration of Albanian migrants. Depending on the country of destination, circular migrants seek for seasonal employment in construction, farming and tourism in Greece and temporary employment in manufacturing, construction and services in Italy (Vadean and Piracha, 2010, p. 473). 
${ }^{19}$ Nekby (2006) also shows that better education increases the probability to leave Sweden in order to migrate to a third country. Using quasi-exogenous staged Norwegian school reform data, Machin, Pelkonen and Salvanas (2012) have demonstrated that compulsory education has a causal impact on regional labor mobility. They suggest that part of the US-Europe difference in labor mobility, as well as the European North-South difference, is likely to be related to different levels of education across those regions.

${ }^{20}$ See Zapata-Barrero et al. (2012) for a first analysis of this success.

${ }^{21}$ For a more detailed description of all those and many other projects funded by the European Commission please consider the corresponding communication (COM, 2007).

22 See the chapter by Plaza on Diaspora Resources and Policies (forthcoming in 2013). 